\title{
Thyroid function and effect of aging in combined hetero/homozygous mice deficient in thyroid hormone receptors $\alpha$ and $\beta$ genes
}

\author{
R E Weiss ${ }^{1}$, O Chassande ${ }^{2}$, E K Koo ${ }^{1}$, P E Macchia ${ }^{1}$, K Cua ${ }^{1}$, \\ J Samarut ${ }^{2}$ and $S$ Refetoff ${ }^{1,3}$ \\ ${ }^{1}$ Department of Medicine, Universty of Chicago, Chicago, Illinois 60637, USA \\ ${ }^{2}$ Laboratoire de Biologie Moleculaire et Cellulaire de l'Ecole Normale Superieure de Lyon, Lyon, France \\ ${ }^{3}$ Department of Pediatrics, University of Chicago, Chicago, Illinois 60637, USA \\ (Requests for offprints should be addressed to R E Weiss, Thyroid Study Unit - MC 3090, Department of Medicine, Room M-376, University of Chicago, \\ 5841 S. Maryland Ave, Chicago, Illinois 60637, USA; Email: rweiss@medicine.bsd.uchicago.edu)
}

\begin{abstract}
The maintenance of thyroid hormone (TH) homeostasis is dependent on the synthesis and secretion of TH regulated by TSH. This is achieved, in turn, by the negative feedback of TH on TSH secretion and synthesis, which requires the interaction with TH receptors (TRs). Derived by alternative splicing of two gene transcription products, three TRs (TR $\beta 1, T R \beta 2$ and TR $\alpha 1$ ) interact with TH while another, TR $\alpha 2$, binds to DNA but not to TH. In this study we compare the results of thyroid function tests in mice with deletions of the $\operatorname{TR} \alpha$ and $\operatorname{TR} \beta$ genes alone and present novel data on mice that are double homozygous and combined heterozygous. Homozygous deletions of both the $\operatorname{TR} \alpha$ and $\operatorname{TR} \beta$ in the same mouse (TR $\alpha_{\mathrm{o}} / \mathrm{o}$; TR $\beta-/-$ ) resulted in serum TSH values only slightly lower than those in athyreotic, Pax8 knockout mice. Whereas the absence of $\operatorname{TR} \alpha$ alone does not cause resistance to $\mathrm{TH}$, the absence of $\mathrm{TR} \beta$ in the presence of TR $\alpha$ results in a 205, 169, 544\% increase in serum
\end{abstract}

thyroxine $\left(\mathrm{T}_{4}\right)$, triiodothyronine $\left(\mathrm{T}_{3}\right)$ and TSH concentrations respectively. However, in the absence of TR $\beta$, loss of one TR $\alpha$ allele can worsen the resistance to TH with a 243 and $307 \%$ increase in $\mathrm{T}_{4}$ and $\mathrm{T}_{3}$ respectively. Similarly, while the heterozygous mouse with a single $\operatorname{TR} \beta$ allele shows no alteration in thyroid function, the concomitant deletion of $\operatorname{TR} \alpha$ brings about mild but significant resistance to TH. Furthermore, the severity of the resistance to $\mathrm{TH}$ was noted to decrease with age in parallel with the decrease in serum free $T_{4}$ values also seen in wild-type mice. These results demonstrate that (1) unliganded $\operatorname{TR} \alpha$ or $\operatorname{TR} \beta$ are not absolutely necessary for the upregulation of TSH; (2) TR $\beta$ but not TR $\alpha$ is sufficient for TH-mediated downregulation of TSH; and (3) TR $\alpha$ may partially substitute for TR $\beta$ in mediating a partial TH-dependent TSH suppression.

Journal of Endocrinology (2002) 172, 177-185

\section{Introduction}

Thyroid hormone (TH) is essential for normal growth and development as well as for the maintenance of metabolic activity in the adult. TH secretion by the thyroid gland is under the control of pituitary thyrotropin (TSH). An important regulator of TSH synthesis and secretion is the negative feedback of TH on TSH gene transcription. This is mediated by intranuclear TH receptors (TRs). Two TR genes have been identified, TR $\alpha$ and $\operatorname{TR} \beta$, each generating two major proteins by alternative splicing. Three of these, $\alpha 1, \beta 1$ and $\beta 2$, bind TH (Sap et al. 1986, Weinberger et al. 1986, Hodin et al. 1989, Lazar 1993). A fourth product, TR $\alpha 2$, binds to thyroid hormone response elements but, due to a sequence difference at the ligand binding domain, it does not bind TH or function as a TR proper (Mitsuhashi et al. 1988). Additional, minor transcripts of the TR $\alpha$ gene that do not bind TR and may act as competitive inhibitors of $\mathrm{TH}$ action are $\Delta \alpha 1, \Delta \alpha 2$ (Chassande et al. 1997) and rev-erbA $\alpha$ (Spanjaard et al. 1994). Two additional TR $\beta$ isoforms which are a result of alternative splicing have been described in most rat tissues (except testes) - TR $\beta 3$ which acts as a functional TR and $\operatorname{TR} \beta \Delta 3$ that lacks the DNA binding domain but retains a ligand binding activity and has a potent dominant-negative effect (Williams 2000). The four principal TR proteins are expressed in the pituitary but their relative role in the regulation of the pituitary-thyroid axis has not been clearly defined. The study of this axis in mice deficient in one or more of the TR genes provides a means to determine the functional role of the individual receptors. Several knockout mice with deletions of the $\operatorname{TR} \alpha$ and $\operatorname{TR} \beta$ in various 
combinations have been generated (Forrest et al. 1996b, Fraichard et al. 1997, Wikström et al. 1998, Gauthier et al. 1999, Göther et al. 1999). However, comparison of the serum TH and TSH levels in these mice as a means to assess the sensitivity of feedback regulation requires measurements using the same assays. This is particularly important for the determination of TSH concentration in mouse serum. In this report we describe the effect of deletion of one or more TRs and the relative importance of $\operatorname{TR} \alpha$ and $\operatorname{TR} \beta$ in the regulation of the pituitarythyroid axis in the mouse. We demonstrate that mice deficient in TR $\beta$ become even more resistant to $\mathrm{TH}$ when one of the TR $\alpha$ alleles is also deleted. Furthermore, mice completely deficient in TR $\alpha$, which by itself does not produce a TH-resistant phenotype, become $\mathrm{TH}$ resistant when one of the TR $\beta$ genes is deleted. Our results suggest functional overlap of TR isoforms and dose dependency in the feedback inhibition of pituitary TSH.

\section{Materials and Methods}

\section{Mice}

Mice were weaned four weeks after birth and fed a rodent diet (No 5053; Lab Diet, Brentwood, MO, USA) containing $0.53 \mathrm{ppm}$ iodine and were given tap water available ad libitum. They were housed, 3 to 5 mice per cage, in a controlled environment at $19{ }^{\circ} \mathrm{C}$ and under $12 \mathrm{~h}$ alternating darkness and artificial light cycles. All animal experiments were performed according to approved protocols at the University of Chicago by the Institutional Animal Care and Use Committee and the Ecole Normale Superieure de Lyon.

Male mice were used exclusively because of previously reported sex differences in thyroid function tests within the same strain (Pohlenz et al. 1999). Mice were 39-140 days old at the time of blood sampling, with the following exceptions: (1) Pax8 - / - mice were 3 weeks old because, if untreated, survival declines rapidly after this age; (2) the effect of age was studied in male mice 2, 3, 6, 9, 12 and 20 weeks old. In mice aged 6 weeks and older, $300 \mu \mathrm{l}$ blood were obtained by retroorbital vein puncture under light methoxyflurane (Pitman Moore, Mundelein, IL, USA) anesthesia. Bleeding was generally carried out between $0900 \mathrm{~h}$ and $1200 \mathrm{~h}$. Serum was separated by centrifugation and stored at $-20{ }^{\circ} \mathrm{C}$ until analyzed.

The TR $\beta$ knockout mice were produced by insertion of the LacZ-NeoR cassette downstream to the splice site of exon 4 , eliminating the expression of the DNA and ligand binding domains of $\operatorname{TR} \beta 1$ and $\operatorname{TR} \beta 2(\operatorname{TR} \beta-/-)$ (Gauthier et al. 1999). The TR $\alpha$ knockout mice were produced by insertion of the LacZ-NeoR cassette downstream to exon 3 and replacing exons 5 through 7, thus effectively abolishing not only the generation of TR $\alpha 1$ and $\operatorname{TR} \alpha 2$ transcripts but also that of $\operatorname{TR} \Delta \alpha 1$ or TR $\Delta \alpha 2$ $\left(\mathrm{TR} \alpha_{\mathrm{O}} / \mathrm{o}\right)$ by removal of their transcription start point at intron 7 (Gauthier et al. 2001). The gene sequence for rev-erbA $\alpha$ protein encoded by the opposite strands for the TR $\alpha$ (Spanjaard et al. 1994) remains intact. In both sets of mice the recombinant embryonic stem (ES) cells were derived from $129 \mathrm{sv}$ mice and were implanted into C57BL/6 recipient blastocysts. C57BL/6 mice were mated to each chimeric mouse and then back-crossed 3-4 times into the same strain, thereby diluting the $129 \mathrm{sv}$ background. Separate wild-type mice were maintained for the TR $\alpha_{\mathrm{o}} / \mathrm{o}(n=18)$ and $\beta-/-(n=54)$ mice. Wild-type mice were also produced from backgrounds of the Pax8 knockout mice (Pax8 - / - ) $(n=7)$ and separate wild-type with the background of the SRC-1 knockout (SRC$1-/-)$ mice $(n=17)$. The SRC-1-/- and the Pax8 $-/-$ mice were also produced with recombinant ES cells from 129Sv mice and were implanted into C57BL/ 6-derived blastocysts. Offspring were outbred into C57BL/6 mice at least 5 times to dilute the $129 \mathrm{sv}$ background. Thyroid function tests for each of these wild-type mice are reported separately, but there was no significant difference in the values among them. The serum samples from Pax8 $-/-$ mice were provided by Drs Ahmed Mansouri and Peter Grüss (Mansouri et al. 1998) and those from SRC-1-/- mice were from Drs Jianming Xu and Bert O'Malley (Weiss et al. 1999).

\section{Induction of hypothyroidism and treatment with $\mathrm{TH}$}

$\mathrm{TH}$ deficiency was induced in 5 male mice of each type (wild-type, TR $\alpha_{\mathrm{o}} / \mathrm{o}$, and TR $\beta-/-$ ) with a low iodine (LoI) diet containing 0·15\% 5-propyl-2-thiouracil (PTU) as described (Weiss et al. 1997). On the 14th day of PTU treatment, TSH releasing hormone $(\mathrm{TRH})$ stimulation tests were performed in these mice as well as in a similar number of mice from each genotype maintained on a normal diet. Blood samples were obtained from the tail vein before and $15 \mathrm{~min}$ after the i.p. administration of $0.275 \mu \mathrm{g}$ TRH. We had previously determined that the peak response of TSH to TRH is at $15 \mathrm{~min}$ (data not shown).

In a separate experiment, 15 mice from each group received the PTU/LoI diet and 15 mice from each group were placed on a normal diet. On the 11th day, mice of each genotype on the different diets were divided into 3 groups ( 5 mice per group). The mice fed the normal diet were given daily i.p. injections of vehicle, 0.2 or $0.8 \mu \mathrm{g}$ L-triiodothyronine $\left(\mathrm{L}-\mathrm{T}_{3}\right) / 100 \mathrm{~g}$ body weight for 4 days while the PTU-fed mice received daily i.p. injections of vehicle, 1.0 or $2.5 \mu \mathrm{g}$ $\mathrm{L}^{-\mathrm{T}_{3}} / 100 \mathrm{~g}$ body weight for 4 days with the PTU diet given throughout the $\mathrm{L}-\mathrm{T}_{3}$ and vehicle treatment period. On the morning of the 5th day, TRH stimulation tests were performed as described above. Serum $\mathrm{T}_{3}$ concentrations achieved at different times after administration of $\mathrm{L}-\mathrm{T}_{3}$ were not different among the different genotypes of mice (Macchia et al. 2001). 


\section{Hormone measurements}

Serum total thyroxine $\left(\mathrm{TT}_{4}\right)$ and $\mathrm{T}_{3}\left(\mathrm{TT}_{3}\right)$ concentrations were measured by coated tubes RIAs (DPC, Diagnostic Products, Los Angeles, CA, USA) using 25 and $50 \mu \mathrm{l}$ serum respectively. The sensitivities of these assays are $0 \cdot 2 \mu \mathrm{g} \mathrm{T} / 4 / \mathrm{dl}(2.6 \mathrm{nmol} / \mathrm{l})$ and $20 \mathrm{ng} \mathrm{T}_{3} / \mathrm{dl}(0.3 \mathrm{nmol} / \mathrm{l})$. The inter-assay coefficients of variation are $5 \cdot 4,4 \cdot 2$ and $3.6 \%$ at $3 \cdot 8,9 \cdot 4$ and $13.7 \mu \mathrm{g} / \mathrm{dl}$ for $\mathrm{T}_{4}$ and $7 \cdot 7,7 \cdot 1$ and $6 \cdot 2 \%$ at 32,53 and $110 \mathrm{ng} / \mathrm{dl}$ for $\mathrm{T}_{3}$. Free $\mathrm{T}_{4}\left(\mathrm{FT}_{4}\right)$ and free $\mathrm{T}_{3}\left(\mathrm{FT}_{3}\right)$ were estimated by calculating the free indexes $\left(\mathrm{FT}_{4} \mathrm{I}\right.$ and $\left.\mathrm{FT}_{3} \mathrm{I}\right)$ using the respective total hormone values and the resin $\mathrm{T}_{4}$ uptake ratio (Robin et al. 1971).

Serum TSH was measured in $50 \mu \mathrm{l}$ serum using a sensitive, heterologous, disequilibrium, double antibody precipitation RIA as described (Pohlenz et al. 1999). The sensitivity of this assay was $5-10 \mathrm{mU} / 1$. The intra-assay and interassay coefficients of variation were respectively: 16 and $27 \%$ at $20 \mathrm{mU} / 1,6 \cdot 3$ and $8 \cdot 2 \%$ at $200 \mathrm{mU} / 1,5 \cdot 4$ and $9 \cdot 8 \%$ at $850 \mathrm{mU} / 1,10$ and $24 \%$ at $2000 \mathrm{mU} / 1$. Samples containing more than 1000 and more than $10000 \mathrm{mU}$ TSH/1 were diluted 10- to 100-fold, respectively, with ' 0 ' TSH mouse serum obtained from wild-type mice treated with a suppressive dose of $\mathrm{T}_{4}$ (Pohlenz et al. 1999).

\section{Data analysis}

Values are reported as means \pm standard deviation or standard error where indicated. $P$ values were calculated by two-way ANOVA when comparing mice of different genotypes and treatment, and by the unpaired Student's $t$-test when comparisons were made within the same genotype, using the Statview 5.0 program (SAS Institute, Inc., Cary, NC, USA).

\section{Results}

Thyroid function tests were determined in mice lacking various combinations of the $\operatorname{TR} \alpha$ and $\operatorname{TR} \beta$ genes (Table 1). Four wild-type substrains of C57BL/6 mice were also evaluated that corresponded to the $\operatorname{TR} \alpha, \operatorname{TR} \beta$, Pax $8-/-$ and SRC-1-/- mice; however there was no significant difference in any of the determinations among these 4 substrains of mice (Fig. 1). Data from the wild-type mice matched to the $\operatorname{TR} \alpha$ and $\operatorname{TR} \beta$ knockout mice were combined into a single group since they were generated by backcrossing with the same strain (Table 1, wild-type). Elevation of TH levels without suppression of serum TSH is usually indicative of resistance to TH at the level of the thyrotropes. Mice completely deficient in TR $\alpha$ gene products (TR $\alpha_{\mathrm{o}} / \mathrm{o}$ ) showed no important differences in basal thyroid function tests compared with the wild-type mice except for slightly but significantly lower serum $\mathrm{T}_{4}$ concentrations. The lower mean $\mathrm{FT}_{4} \mathrm{I}$ and $\mathrm{FT}_{3} \mathrm{I}$ did not reach statistical significance. In contrast, there was a clear elevation in $\mathrm{FT}_{4} \mathrm{I}(2 \cdot 5$-fold $), \mathrm{FT}_{3} \mathrm{I}(1 \cdot 6$-fold $)$ and TSH $(5 \cdot 4$-fold $) \quad(P<0 \cdot 0005)$ in the homozygous TR $\beta-/-$ mice, compatible with resistance to TH. The mice homozygous for the combined $\operatorname{TR} \alpha$ and $\operatorname{TR} \beta$ deletions displayed higher TH levels even though the absence of TR $\alpha$ alone did not produce TH resistance. $\mathrm{FT}_{4} \mathrm{I}, \mathrm{FT}_{3} \mathrm{I}$, and $\mathrm{TSH}$ values were, respectively, 14, 124 and 822 times higher than those of wild-type mice. The elevation of TSH in the combined TR $\alpha / \operatorname{TR} \beta$ knockout mice was only half that found in the athyreotic Pax8 gene knockout mice (Pohlenz et al. 1999) (Fig. 1).

Mice heterozygous for a deletion of only one allele of the $\operatorname{TR} \beta(\operatorname{TR} \beta-/+)$ or $\operatorname{TR} \alpha(\operatorname{TR} \alpha \mathrm{o} /+)$ genes have thyroid function tests that are not different from the wild-type mice (Forrest et al. 1996b, Gauthier et al. 1999). However, when one allele of the $\operatorname{TR} \beta$ is absent in combination with complete deletion of $\operatorname{TR} \alpha$ (which alone causes no $\mathrm{TH}$ resistance), increases of 1.5 -fold in $\mathrm{FT}_{4} \mathrm{I}$, 1.3-fold in $\mathrm{FT}_{3} \mathrm{I}$ and 1.7-fold in $\mathrm{TSH}$ were observed compared with wild-type mice, suggestive of TH resistance (Table 2 and Fig. 1). Similarly, when one allele of the TR $\alpha$ was absent together with complete deletion of the $\operatorname{TR} \beta\left(\operatorname{TR} \alpha_{\mathrm{o}} /+; \operatorname{TR} \beta-/-\right)$, the mice displayed a further $1 \cdot 7-, 1 \cdot 8$ - and 3.6-fold increase in the $\mathrm{FT}_{4} \mathrm{I}, \mathrm{FT}_{3} \mathrm{I}$ and TSH respectively compared with $\operatorname{TR} \beta-/-$ mice with preservation of both TR $\alpha$ alleles (Table 2 and Fig. 1). This suggests that $\operatorname{TR} \alpha$ may act to attenuate the resistance to $\mathrm{TH}$ at the level of the pituitary.

$\mathrm{FT}_{4} \mathrm{I}$ levels decrease with age in the TR $\alpha \mathrm{o} / \mathrm{o}$, $\operatorname{TR} \beta-/-$ and in TR $\alpha \mathrm{O} / \mathrm{o} ; \mathrm{TR} \beta-/-$ mice as seen in wild-type mice (Fig. 2, Table 3). However results in the double knockout mouse are based on only two animals. The $\mathrm{FT}_{4} \mathrm{I}$ levels at 2 weeks of age were consistently and significantly higher than at older ages. Wild-type and TR $\beta-/-$ mice had higher $\mathrm{FT}_{4} \mathrm{I}$ levels at 6 weeks compared with older mice at 20 weeks, whereas the $\mathrm{TR} \alpha \mathrm{O} / \mathrm{o}$ mice were not different at these time points.

The responses of serum TSH to TRH in intact and TH-deprived mice are shown in Fig. 3. Mice fed a normal diet had robust TSH responses to TRH administration. Although all three genotypes (wild-type, TRao/o, TR $\beta-/-)$ reached a similar peak TSH value, the percentage increment was significantly less for the TR $\beta-/-$ compared with wild-type (only $4 \cdot 1 \% \pm 1 \cdot 4$ versus $69 \cdot 5 \% \pm 26 \cdot 7, P=0 \cdot 006)$ or $\mathrm{TR} \alpha_{\mathrm{o}} / \mathrm{o} \quad(80 \cdot 8 \% \pm$ $61 \cdot 9, P=0 \cdot 026)$. However TH-deprived mice had no TSH response to TRH stimulation. The lack of a significant increase in TSH after TRH stimulation is contrary to the hyper-responsiveness seen in hypothyroid humans (Saberi \& Utiger 1975).

The responses of serum TSH to TRH before and after the administration of two incremental doses of $\mathrm{L}-\mathrm{T}_{3}$ are shown in Fig. 4. In mice fed a normal diet, the higher dose 


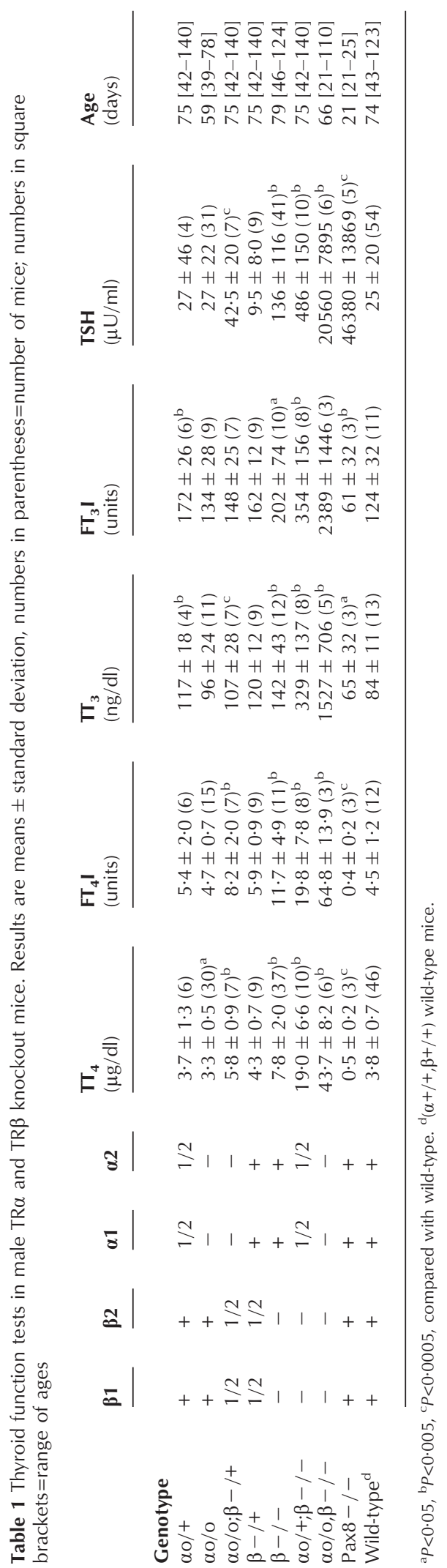




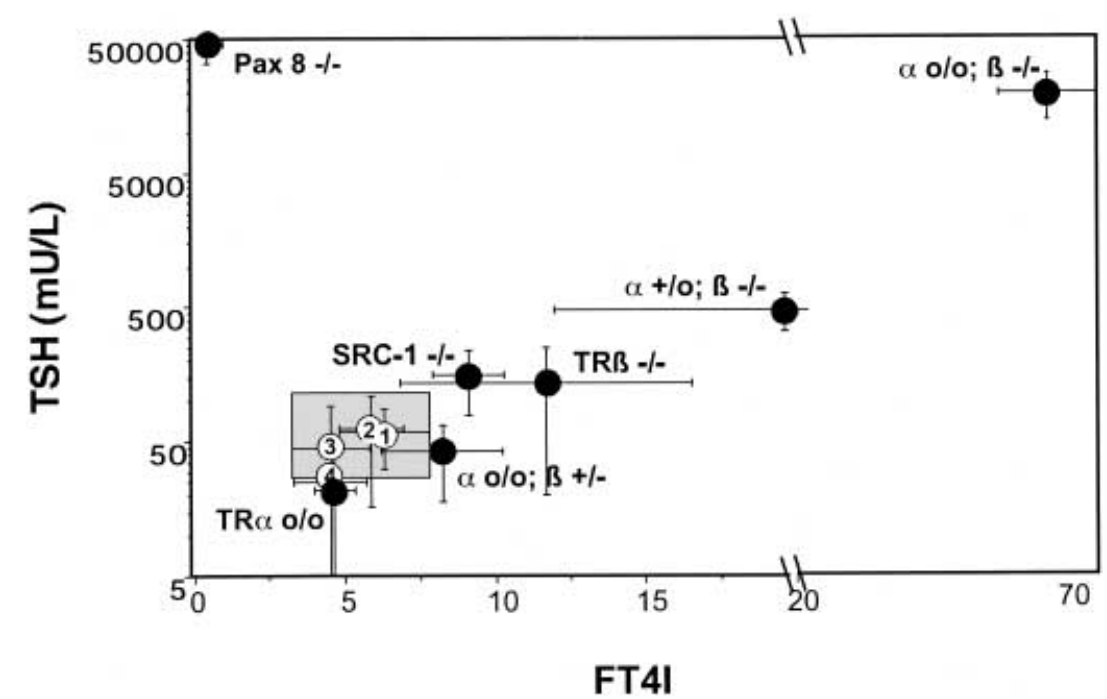

Figure 1 Relationship of serum $\mathrm{FT}_{4} \mathrm{I}$ and TSH in mice lacking one or more TRs (solid symbols; error bars are standard deviation). The shaded area indicates the 4 different wild-type mouse strains tested (open symbols). Wild-type mice were obtained by back-crossing into C57BL/6 mice with TRao/o $(1 ; n=18) ; \operatorname{TR} \beta-/-(2 ; n=54) ;$ Pax $8-/-$ $(3 ; n=7)$; or SRC-1 $-/-(4 ; n=18)$ mice to obtain heterozygotes and then back-crossing to obtain wild-type mice. In each group male mice aged 39-140 days were used, except for the Pax $8-/-$ mice which were 21 days of age due to decreased survival past that age.

of $\mathrm{L}-\mathrm{T}_{3}$ suppressed the TSH response to $\mathrm{TRH}$ by $50 \%$ in the wild-type compared with a $4 \cdot 3 \%$ increase in the TR $\beta-/-$ mice (2-way ANOVA, $P<0 \cdot 001$ ) and a $78 \%$ decline in the TR $\alpha_{\mathrm{o}} / \mathrm{o}$ mice $(P<0 \cdot 001)$. In TH-deprived mice, the higher dose of $\mathrm{L}_{3} \mathrm{~T}_{3}$ suppressed the TSH response by $>90 \%$ in the wild-type, $\operatorname{TR} \beta-/-$ and TR $\alpha_{0} /$ o mice. Collectively, these data indicate that the feedback regulation of the pituitary-thyroid axis of $\mathrm{TR} \beta-/-$ mice is resistant to TH and that the TR $\alpha_{\mathrm{o}} / \mathrm{o}$ mice are more sensitive to $\mathrm{TH}$.

Of interest is the paradoxical response of TSH to TRH (a 153\% increase; 2-way ANOVA, $P=0.0010$ ) seen in $\operatorname{TR} \beta-/-$ mice on the lower dose of $\mathrm{L}-\mathrm{T}_{3}$ and fed a normal diet, as we reported previously in these mice (Macchia et al. 2001) and in humans homozygous for the TR $\beta$ gene deletion (Refetoff $e$ t al. 1980). This paradoxical response to $\mathrm{L}-\mathrm{T}_{3}$ is not seen in $\mathrm{TR} \beta-/-$ mice fed a PTU/LoI diet.

\section{Discussion}

The relative serum levels of TH and TSH reflect the sensitivity of the pituitary to the feedback regulation of $\mathrm{TSH}$ by TH which is, in turn, dependent on the interaction of TH with TRs in the thyrotropes. Selective removal of one or more TR alleles would allow one to determine the role of each TR isoform and its relative importance in the mediation of $\mathrm{TH}$ action at the level of the pituitary gland. We present novel data on thyroid function of mice that are double heterozygous or homozygous in all combinations suggesting different and overlapping roles for $\operatorname{TR} \alpha$ and $\operatorname{TR} \beta$. Lack of $\operatorname{TR} \beta$ in the mouse has been shown to cause resistance to $\mathrm{TH}$, i.e. elevated levels of $\mathrm{T}_{4}, \mathrm{~T}_{3}$ and TSH (Forrest 1994, Forrest et al. 1996a, Weiss et al. 1997).

The upregulation of TSH is relatively independent of the presence of unliganded $\operatorname{TR} \beta$ and $\operatorname{TR} \alpha$ genes as

Table 2 Statistical differences ( $P$ values) in the thyroid function tests of compound hetero/homozygous TR $\alpha$ and TR $\beta$ knockout mice ${ }^{a}$

\begin{tabular}{|c|c|c|c|c|c|}
\hline & $\Pi_{4}$ & $\mathrm{FT}_{4} \mathrm{I}$ & $\mathrm{TT}_{3}$ & $\mathrm{FT}_{3} \mathrm{I}$ & TSH \\
\hline \multicolumn{6}{|l|}{ Genotype } \\
\hline TR $\alpha \mathrm{o} / \mathrm{o} ; \operatorname{TR} \beta+/+$ vs TR $\alpha \mathrm{o} / \mathrm{o} ; \operatorname{TR} \beta+/-$ & $<0 \cdot 001$ & $<0.001$ & $0 \cdot 016$ & 0.003 & $0 \cdot 020$ \\
\hline $\operatorname{TR} \alpha+/+; \operatorname{TR} \beta-/-$ vs $\operatorname{TR} \alpha+/ 0 ; \operatorname{TR} \beta-/-$ & $0 \cdot 05$ & $0 \cdot 001$ & $0 \cdot 001$ & Not significant & Not significant \\
\hline
\end{tabular}

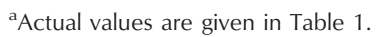



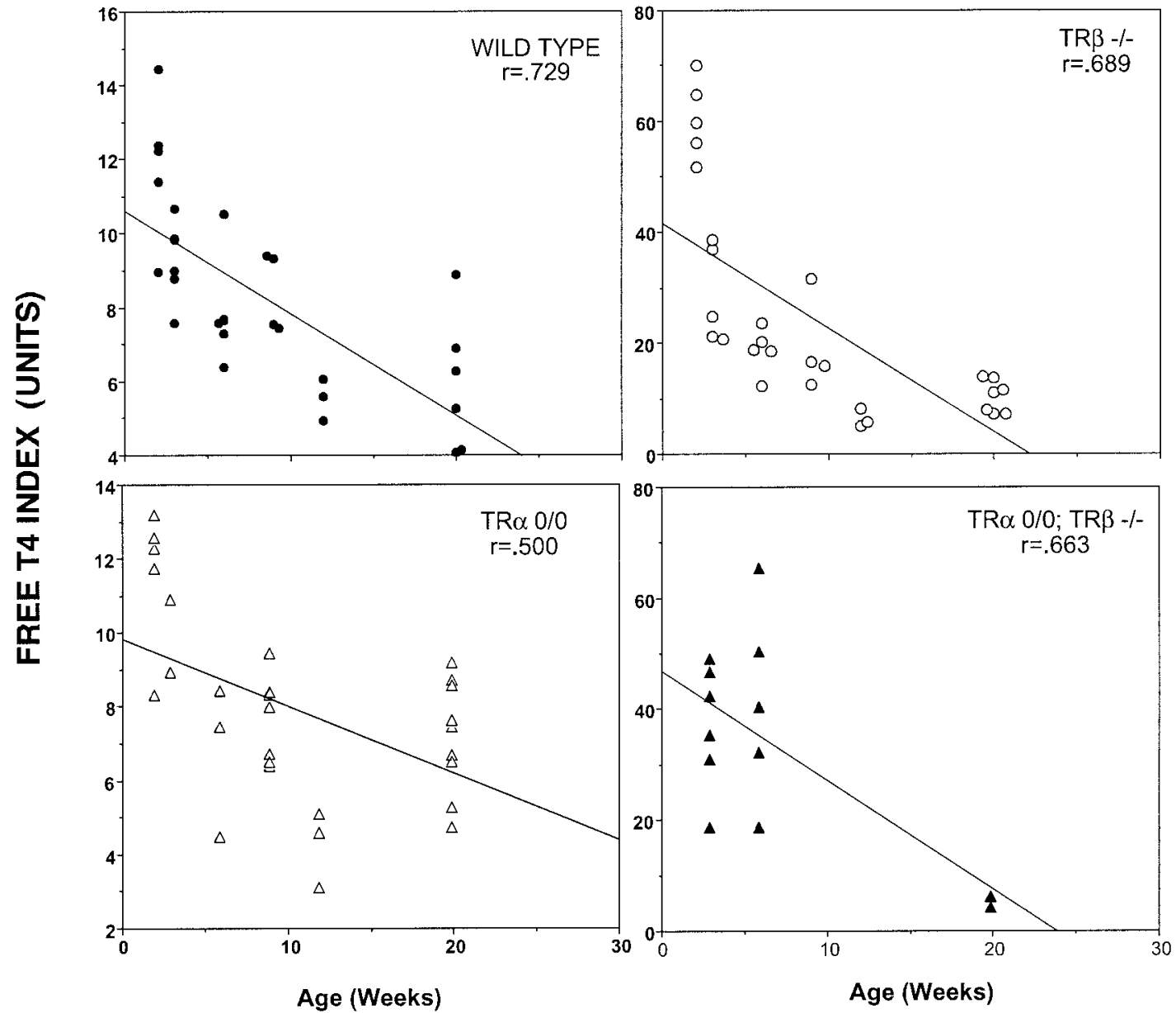

Figure 2 Effect of age on serum $\mathrm{FT}_{4} \mathrm{l}$ levels in combined TR $\alpha \mathrm{o} / \mathrm{o} ; \mathrm{TR} \beta-/-$ mice as compared with TR $\beta-/-$, TR $\alpha \mathrm{O} / \mathrm{O}$, and wild-type mice. Individual values are shown for serum $\mathrm{FT}_{4} \mathrm{I}$ concentrations in mice of different ages.

Table 3 Effect of age on serum $\mathrm{FT}_{4} \mathrm{I}$ values (means \pm S.E.) in wild-type, TR $\alpha \mathrm{O} / \mathrm{o}$, TR $\beta-/-$, and combined TR $\alpha \mathrm{O} / \mathrm{o} ; \mathrm{TR} \beta-/-$ mice. Numbers in parentheses $=$ number of mice

\section{Age (weeks)}

\begin{tabular}{|c|c|c|c|c|c|}
\hline 2 & 3 & 6 & 9 & 12 & 20 \\
\hline $\begin{array}{l}11 \cdot 9 \pm 0 \cdot 9 \\
(5) \\
11 \cdot 6 \pm 0 \cdot 9 \\
(5) \\
60 \cdot 5 \pm 3 \cdot 2 \\
(5) \\
\text { Not done }\end{array}$ & $\begin{array}{l}9 \cdot 3 \pm 0 \cdot 4^{\mathrm{a}} \\
(6) \\
9 \cdot 9 \pm 1 \cdot 0^{\mathrm{a}} \\
(3) \\
30 \cdot 3 \pm 3 \cdot 6^{\mathrm{b}} \\
(6) \\
36 \cdot 9 \pm 4 \cdot 6 \\
(6)\end{array}$ & $\begin{array}{l}7 \cdot 9 \pm 0 \cdot 6^{b} \\
(6) \\
6 \cdot 8 \pm 1 \cdot 2^{b} \\
(3) \\
19 \cdot 6 \pm 1 \cdot 7^{b} \\
(6) \\
38 \cdot 9 \pm 10 \cdot 0 \\
(4)\end{array}$ & $\begin{array}{l}8 \cdot 4 \pm 0 \cdot 5^{a} \\
(4) \\
7 \cdot 6 \pm 0 \cdot 4^{b} \\
(9) \\
19 \cdot 2 \pm 4 \cdot 3^{b} \\
\text { (4) } \\
\text { Not done }\end{array}$ & $\begin{array}{l}5 \cdot 6 \pm 0 \cdot 3^{b} \\
(3) \\
4 \cdot 2 \pm 0 \cdot 6^{b} \\
(3) \\
6 \cdot 4 \pm 0 \cdot 9^{b} \\
(3) \\
\text { Not done }\end{array}$ & $\begin{array}{l}5 \cdot 7 \pm 0 \cdot 7^{\mathrm{b}} \\
(7) \\
7 \cdot 2 \pm 0 \cdot 5^{\mathrm{b}} \\
(9) \\
10 \cdot 4 \pm 1 \cdot 1^{\mathrm{b}} \\
(7) \\
5 \cdot 74 ; 3 \cdot 90^{*}\end{array}$ \\
\hline
\end{tabular}

\section{Genotype}

Wild-type

$\mathrm{TR} \alpha \mathrm{O} / \mathrm{O}$

$\operatorname{TR} \beta-/-$

$\mathrm{TR} \alpha \mathrm{O} / \mathrm{O} ; \mathrm{TR} \beta-/-$

$$
\text { (5) }
$$

$36 \cdot 9 \pm 4 \cdot 6$$$
\text { (6) }
$$ 

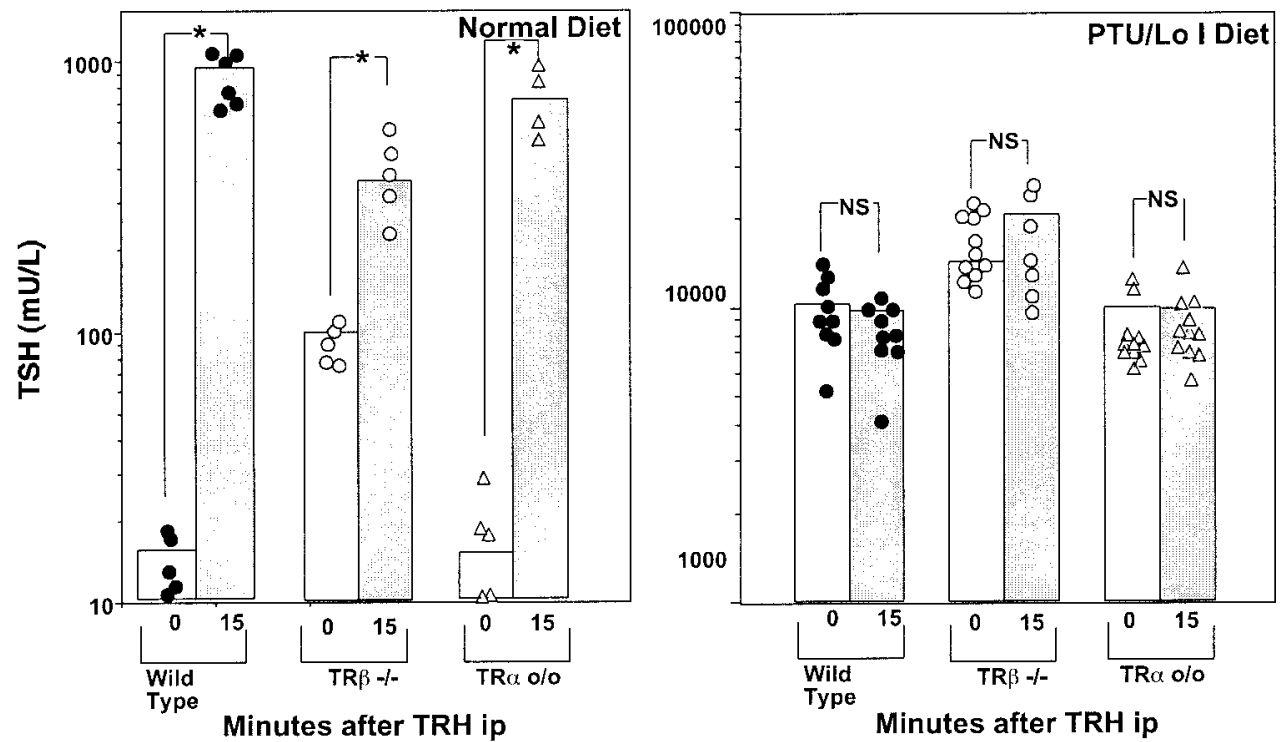

Figure 3 Serum TSH response to TRH. Groups of different mice maintained on a normal diet (right panel) or a diet containing low iodine and PTU (PTU/Lol, left panel) were monitored before (open bars) and 15 min after (shaded bars) TRH stimulation. Indivivdual values are also shown. Mice were studied under PTU/Lol treatment in order to bring baseline values of TSH to the same range in all the genotypes studied. Brackets above bars indicate the $P$ values between 0 min and 15 min post TRH injection. NS, not significant, ${ }^{*} P<0 \cdot 001$. Note the lack of stimulation with TRH in the TH-deprived mice and the difference in the TSH scales in the two panels.

evidenced by the high TSH values attained in mice devoid of these two receptors. This suggests that TRs are involved mainly in the transcriptional repression of TSH and not in TSH gene activation. In fact, the serum TSH values in the completely TR-deficient mice (TR $\alpha_{\mathrm{o}} / \mathrm{o} ; \mathrm{TR} \beta-/-$ ) are not substantially lower than those measured in athyreotic, Pax8 $-/-$ mice. Relative to values in the wild-type mice, mean TSH levels in TR-deficient mice were 822-fold higher as compared with 1855-fold higher in Pax $8-/-$ mice. Since TSH is downregulated by TH, it is the absence of $\mathrm{TH}$ that results in increased transcription of TSH mRNA. This has been demonstrated in wild-type hypothyroid mice in which there was an increase in both $\alpha$ subunit and TSH $\beta$ mRNAs (Chin et al. 1985, Gurr et al. 1986). This effect appears to require the stimulation by TSH releasing hormone (Abel et al. 1999, Shibusawa et al. 2000).

Eliminating only one TR $\beta$ allele is not sufficient to produce a phenotype distinct from the wild-type mouse. Furthermore, the absence of TR $\alpha$ in the presence of TR $\beta$ does not produce the TH resistant phenotype. However, the absence of only one TR $\beta$ allele in TR $\alpha$-deficient mice results in significant TH resistance. Therefore, the presence of TR $\alpha$ compensates for haploinsufficiency resulting from the lack of one TR $\beta$ allele. In other words, TR $\alpha$ can partially substitute for TR $\beta$.

In addition to TR $\beta 1$ and TR $\beta 2$, a third isoform, TR $\beta 3$, has been described in rat which could potentially mediate

\section{A. Normal Diet}

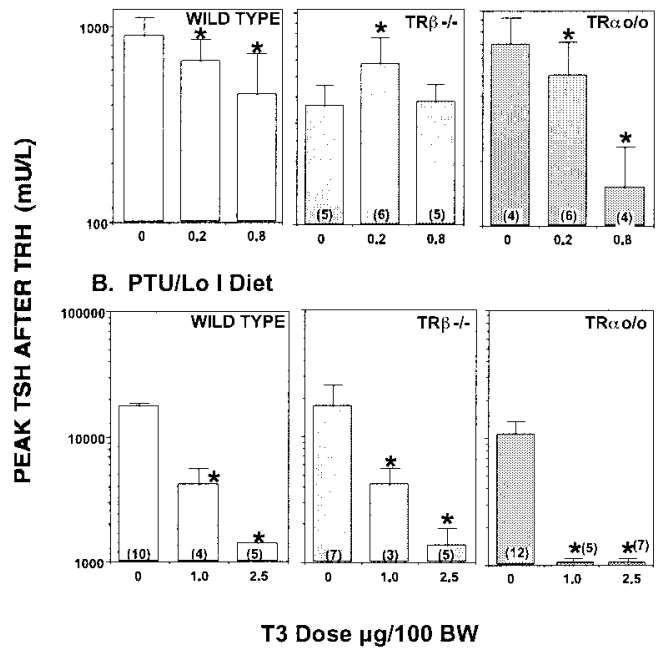

Figure 4 Effect of TH on the TSH response to TRH. Groups of mice from the 3 phenotypes were treated for 4 days with 2 different doses of $\mathrm{L}^{-\mathrm{T}_{3}}$ or with the vehicle only (0). The upper panels show the results for mice fed a normal diet and the bottom panels show results for mice fed a PTU/Lol diet. Data shown are serum TSH values $15 \mathrm{~min}$ after TRH administration. The number of mice in each group is indicated within the bars. ${ }^{*} P<0 \cdot 001$ compared with vehicle for each treatment. Note the paradoxical increase in TSH in the TR $\beta-/-$ mice on a normal diet and receiving $0 \cdot 2 \mu \mathrm{g} \mathrm{L}-\mathrm{T}_{3} / 100 \mathrm{~g}$ body weight $(\mathrm{BW})$ and the greater suppressive effect of $0 \cdot 8 \mu \mathrm{g} \mathrm{L}-\mathrm{T}_{3} / 100 \mathrm{~g} \mathrm{BW}$ in the TR $\alpha \mathrm{o} / \mathrm{o}$ mice on a normal diet and of $1.0 \mu \mathrm{g} \mathrm{L}-\mathrm{T}_{3} / 100 \mathrm{~g} \mathrm{BW}$ in the TR $\alpha \mathrm{O} / \mathrm{o}$ mice on a PTU/Lol diet. 
the effects of TH (Williams 2000). This isoform, however, is unlikely to be involved in the TR $\beta$ knockout mouse, as these mice are generated by removal of exons 4 and 5 (Gauthier et al. 1999). These exons are shared by TR $\beta 1$, TR $\beta 2$, TR $\beta 3$ as well as the truncated TR isoforms (TR $\beta \Delta 1, \operatorname{TR} \beta \Delta 2$ and TR $\beta \Delta 3$ ). Direct measurement of TR $\beta 3$ has not been performed because TR $\beta 3$ has not been demonstrated in mouse and sequences are not available for gene amplification. Similarly, in the TR $\alpha_{0} / \mathrm{o}$ mouse one needs to be assured that there are no other $\operatorname{TR} \alpha$ isoforms expressed in the pituitary that could mediate $\mathrm{TH}$ action. The construction of the TR $\alpha_{\mathrm{o}} / \mathrm{o}$ mouse would not allow for any other known $\operatorname{TR} \alpha$ isoforms to be formed (Gauthier et al. 2001). Furthermore, whereas TR $\alpha 1$ and TR $\alpha 2$ could be detected by RT-PCR in pituitaries of wild-type mice, these isoforms could not be detected in the pituitaries of TR $\alpha_{0} / \mathrm{o}$ mice (authors' personal observations).

Differences in the action of $\operatorname{TR} \beta$ and $\operatorname{TR} \alpha$ can be due to different levels of expression of the isoforms in the pituitary. TR $\beta$ is more abundant in the pituitary than TR $\alpha$ in human (Falcone et al. 1992) and rat (Hodin et al. 1989), which explains the increased magnitude of $\mathrm{TH}$ resistance seen in TR $\beta-/-$ compared with the TR $\alpha_{0} / \mathrm{o}$ mice. Data suggesting higher affinity of the $\mathrm{T}_{3}$-ligand for the TR $\beta$ than for the TR $\alpha 1$ isoform may play a role (Schueler et al. 1990). Finally, the specificity of interaction of the TR $\alpha$ and TR $\beta$ with other elements of the transcriptional machinery may be responsible for a dominant role of TR $\beta$ on TSH regulation. We have previously shown that SRC-1 knockout mice have TH and TSH levels consistent with resistance which is of a milder degree compared with TR $\beta-/-$ mice (Weiss et al. 1999). Although there is no in vitro evidence to suggest which TR isoforms interact preferentially with SRC-1, it is possible that isoform-specific recruitment of cofactors is important in the TH-mediated regulation of TSH expression. TR $\beta 2$ has impaired functional interactions with corepressors (Hollenberg et al. 1996) which may be due to interaction of the amino terminus with coactivators (Oberste-Berghaus et al. 2000) or interaction with other corepressors (Yang et al. 1999).

The observation that hypothyroid mice, unlike humans, do not hyper-respond to TRH stimulation may reflect the physiological difference between the species and could possibly be due to decreased stored TSH in the pituitary glands of hypothyroid mice. However, as in humans (Refetoff et al. 1980), mice deficient in TR $\beta$ show a paradoxical increase in the TSH response to TRH with low suppressive doses of $\mathrm{L}-\mathrm{T}_{3}$. This was not observed when mice were pretreated with PTU, probably due to depletion of pituitary reserves during hypothyroidism.

A significant inverse relationship between age and serum TH levels has been reported in mice (Eleftheriou 1975, Mobley \& Dubuc 1978). This appears to be independent of feedback by $\mathrm{TH}$ since it was also observed in the absence of both TR $\alpha$ and $\operatorname{TR} \beta$. However, we were able to follow only two mice with the combined TR $\alpha_{\mathrm{O}} /$ o; TR $\beta-/-$ genotype. The results reported herein support casual observations that the hormonal resistance in subjects with resistance to $\mathrm{TH}$ seems to improve with age (Refetoff et al. 1993). This reflects the tendency of $T_{4}$ levels to decrease with age in normal subjects as well as in patients with resistance to TH (Weiss \& Refetoff 2000).

\section{Acknowledgements}

The authors wish to thank Ahmed Muqeem for performing the hormone measurements, Drs Mansouri and Grüss for providing serum from Pax- 8 knockout mice and Drs $\mathrm{Xu}$ and O'Malley for providing SRC-1 knockout mice. This work was supported in part by grants from the National Institutes of Health to S R (DK 15070), R E W (DK 58281) and by the Seymour J Abrams Thyroid Research Center.

\section{References}

Abel ED, Kaulbach HC, Campos-Barros A, Ahima RS, Boers M-E, Hashimoto K, Forrest D \& Wondisford FE 1999 Novel insight from transgenic mice into thyroid hormone resistance and the regulation of thyrotropin. Journal of Clinical Investigation $\mathbf{1 0 3}$ 271-279.

Chassande O, Fraichard A, Gauthier K, Flamant F, Legrand C, Savatier P, Laudet V \& Samarut J 1997 Identification of transcripts initiated from an internal promoter in the c-erb-A $\alpha$ locus that encode inhibitors of retinoic acid receptor- $\alpha$ and triiodothyronine receptor activities. Molecular Endocrinology 11 1278-1290.

Chin WW, Shupnik MA, Ross DS, Habener JF \& Ridgway EC 1985 Regulation of the alpha- and thyrotropin beta-subunit messenger ribonucleic acids by thyroid hormones. Endocrinology 116 873-878.

Eleftheriou B 1975 Changes with age in protein-bound iodine (PBI) and body temperature in the mouse. Journal of Gerontology $\mathbf{3 0}$ 417-421.

Falcone M, Miyamoto T, Fierro-Renoy F, Nacchia E \& DeGroot LJ 1992 Antipeptide polyclonal antibodies specifically recognize each human thyroid hormone receptor isoform. Endocrinology 131 2419-2429.

Forrest D 1994 The erbA/thyroid hormone receptor genes in development of the central nervous system. Seminars in Cancer Biology 5 167-176.

Forrest D, Erway LC, Ng L, Altschuler R \& Curran T 1996a Thyroid hormone receptor $\beta$ is essential for development of auditory function. Nature Genetics 13 354-357.

Forrest D, Hanebuth E, Smeyne RJ, Evereds N, Stewart CL, Wehner JM \& Curran T $1996 b$ Recessive resistance to thyroid hormone in mice lacking thyroid hormone receptor $\beta$ : evidence for tissuespecific modulation of receptor function. EMBO Journal 15 3006-3015

Fraichard A, Chassande O, Plateroti M, Roux JP, Trouillas J, Dehay C, Legrand C, Gauthier K, Kedinger M, Malaval L, Rousset B \& Samarut J 1997 The $T_{3} R \alpha$ gene encoding a thyroid hormone receptor is essential for post-natal development and thyroid hormone production. EMBO Journal 16 4412-4420.

Gauthier K, Chassande O, Platerotti M, Roux J-P, Legrand C, Rousset B, Weiss R, Trouillas J \& Samarut J 1999 Different 
functions for the thyroid hormone receptors $\operatorname{TR} \alpha$ and $\operatorname{TR} \beta$ in the control of thyroid hormone production and post-natal development. EMBO Journal 18 623-631.

Gauthier K, Plateroti M, Harvey CB, Williams GR, Weiss RE, Refetoff S, Willott JF, Sundin V, Roux JP, Malaval L, Hara M, Samarut J \& Chassande O 2001 Genetic analysis reveals different functions for the products of the thyroid hormone receptor alpha locus. Molecular and Cellular Biology 21 4748-4760.

Göther S, Wang Z, Ng L, Kindblom JM, Campos Barros A, Ohlsson C, Vennstrom B \& Forrest D 1999 Mice devoid of all known thyroid hormone receptors are viable but exhibit disorders of the pituitary-thyroid axis, growth and bone maturation. Genes Development 13 1329-1341.

Gurr JA, Vrontakis ME, Athanasian EA, Wagner CR \& Kourides IA 1986 Hormonal regulation of thyrotropin alpha and beta subunit mRNAs. Hormone and Metabolic Research 18 382-385.

Hodin RA, Lazar MA, Wintman BI, Darling DS, Koenig RJ, Larsen PR, Moore DD \& Chin WW 1989 Identification of a thyroid hormone receptor that is pituitary-specific. Science 244 76-79.

Hollenberg AN, Monden T, Mandura JP, Lee K \& Wondisford FE 1996 Function of nuclear coreceptor protein on thyroid hormone response elements is regulated by the receptor A/B domain. Journal of Biological Chemistry 271 28516-28520.

Lazar MA 1993 Thyroid hormone receptors: multiple forms, multiple possibilities. Endocrine Reviews 14 184-193.

Macchia PE, Takeuchi Y, Kawai T, Cua K, Gauthier K, Chassande O, Seo H, Hayashi Y, Samarut J, Murata Y, Weiss RE \& Refetoff S 2001 Increased sensitivity to thyroid hormone in mice with complete deficiency of thyroid hormone receptor alpha. PNAS $\mathbf{9 8}$ 349-354.

Mansouri A, Chawdhury K \& Gruss P 1998 Follicular cells of the thyroid gland require Pax8 gene function. Nature Genetics 19 87-90.

Mitsuhashi T, Tennyson GE \& Nikodem VM 1988 Alternative splicing generates messages encoding rat c-erbA proteins that do not bind thyroid hormones. PNAS 85 5804-5805.

Mobley P \& Dubuc P 1978 Thyroid hormone levels in the developing obese hyperglycemic syndrome. Hormone and Metabolic Research 11 37-39.

Oberste-Berghaus C, Zanger K, Hashimoto K, Cohen RN, Hollenberg AN \& Wondisford FE 2000 Thyroid hormone-independent interaction between the thyroid hormone receptor beta2 amino terminus and coactivators. Journal of Biological Chemistry 275 17871792.

Pohlenz J, Muqueem A, Cua K, Weiss RE, Van Sande J \& Refetoff S 1999 Improved radioimmunoassay for measurement of mouse TSH in serum: strain differences in TSH concentration and thyrotropin sensitivity to thyroid hormone. Thyroid 9 1265-1271.

Refetoff S, DeGroot LJ \& Barsano CP 1980 Defective thyroid hormone feedback regulation in the syndrome of peripheral resistance to thyroid hormone. Journal of Clinical Endocrinology and Metabolism 51 41-45.

Refetoff S, Weiss RE \& Usala SJ 1993 The syndromes of resistance to thyroid hormone. Endocrine Reviews 14 348-399.
Robin NI, Hagen SR, Collaço F, Refetoff S \& Selenkow HA 1971 Serum tests for measurement of thyroid function. Hormones $\mathbf{2}$ 266-279.

Saberi M \& Utiger RD 1975 Augmentation of thyrotropin responses to thyrotropin-releasing hormone following small decreases in serum thyroid hormone concentrations. Journal of Clinical Endocrinology and Metabolism 40 435-441.

Sap J, Muñoz A, Damm K, Goldberg Y, Ghysdael J, Lentz A, Beng H \& Vennström B 1986 The c-erb-A protein is a high-affinity receptor for thyroid hormone. Nature 324 635-640.

Schueler PA, Schwartz HL, Strait KA, Mariash CN \& Oppenheimer JH 1990 Binding of 3,5,3'-triiodothyronine $\left(\mathrm{T}_{3}\right)$ and its analogs to the in vitro translational products of $\mathrm{c}$-erbA protooncogenes: differences in the affinity of $\alpha$ - and $\beta$-forms for the acetic acid analog and failure of the human testis and kidney $\alpha-2$ products to bind $\mathrm{T}_{3}$. Molecular Endocrinology 4 227-234.

Shibusawa N, Yamada M, Hirato J, Monden T, Staoh T \& Mori M 2000 Requirement of thyrotropin-releasing hormone for the postnatal functions of pituitary thyrotrophs: ontogeny study of congenital tertiary hypothyroidism in mice. Molecular Endocrinology 14 137-146.

Spanjaard R, Nguyen V \& Chin W 1994 Rat rev-erbA alpha, an orphan receptor related to thyroid hormone receptor, binds to specific thyroid hormone response elements. Molecular Endocrinology 8 286-295.

Weinberger C, Thompson CC, Ong ES, Lebo R, Gruol DJ \& Evans RM 1986 The c-erb-A gene encodes a thyroid hormone receptor. Nature 324 641-646.

Weiss RE \& Refetoff S 2000 Resistance to thyroid hormone. Reviews in Endocrine and Metabolic Disorders 1 97-108.

Weiss RE, Forrest D, Pohlenz J, Cua K, Curran T \& Refetoff S 1997 Thyrotropin regulation by thyroid hormone in thyroid hormone receptor $\beta$-deficient mice. Endocrinology 138 3624-3629.

Weiss RE, Xu J, Ning GJP, O’Malley B \& Refetoff S 1999 Mice deficient in the steroid receptor co-activator 1 (SRC-1) are resistant to thyroid hormone. EMBO Journal 18 1900-1904.

Wikström L, Johansson C, Salto C, Barlow C, Campos Barros A, Baas F, Forrest D, Thorén P \& Vennström B 1998 Abnormal heart rate and body temperature in mice lacking thyroid hormone receptor 1 . EMBO Journal 17 455-461.

Williams GR 2000 Cloning and characterization of two novel thyroid hormone receptor beta isoforms. Molecular and Cellular Biology 20 8329-8342.

Yang Z, Hong S-H \& Privalsky ML 1999 Transcriptional antirepression: thyroid hormone receptor beta- 2 recruits SMRT corepressor but interferes with subsequent assembly of a functional corepressor complex. Journal of Biological Chemistry 274 37131-37138.

Received 12 June 2001

Accepted 27 September 2001 